\title{
Implementasi Kebijakan Pendidikan
}

\section{The Implementation of Educational Policies}

Elih Yuliah

Pengawas Sekolah di Kementrian Agama, Dinas Pendidikan dan Kebudayaan Kota Sukabumi, Jawa Barat, Indonesia

elih.yuliah67@gmail.com

\begin{abstract}
Abstrak
Tujuan implementasi kebijakan adalah untuk menetapkan arah agar tujuan kebijakan dapat teralisasi. Kajian ini bertujuan untuk mendeskripsikan proses implementasi kebijakan termasuk di dalamnya kebijakan pendidikan. Penelitian ini adalah penelitian kualitatif yang bersifat studi pustaka (library research). Data penelitian berupa data kepustakaan terutama buku-buku yang berkaitan dengan implementasi kebijakan pendidikan. Kemudian data yang terkumpul dipilih, disajikan dan dianalisis dengan menggunakan analisis isi (content analysis). Hasil kajian menunjukan bahwa "implementasi" merupakan faktor terpenting dari sebuah kebijakan. Implementasi kebijakan pendidikan merupakan proses yang bersangkut paut dengan perilaku badan administratif sebagai penanggung jawab pelaksanaan program. Proses implementasi bersangkut paut juga dengan faktor hukum, politik, ekonomi, sosial yang langsung maupun tidak langsung berpengaruh terhadap perilaku dari berbagai pihak yang terlibat dalam program. Dalam implementasi kebijakan terdapat proses yang harus dilalui di antaranya yaitu strategi dan pendekatan tertentu yang harus ditempuh, serta beberapa kelengkapan dan kecukupan yang harus dipenuhi. Hal ini tidak lain demi mewujudkan keberhasilan dalam mengimplementasikan kebijakan.
\end{abstract}

Kata Kunci: Implementasi Kebijakan, Kebijakan Pendidikan, Strategi Implementasi Kebijakan

\section{Abstract}

The aims of policy implementation is to set direction untik policy objectives can be realized. This research aims to describe the process of policies implementation including education policies. This research is a qualitative research which is library research. Research data in the form of library data, especially some books about the implementation of educational policies. Then the data collected was selected, presented and analyzed using content analysis. The results of this reseach show that "implementation" is the most important factor of a policies. The implementation of education policies is a process that related with the behavior of administrative institutions as the ones responsibity for implementation of program. The implementation process also related with 
legal, political, economic, social factors that directly or indirectly affect the behavior of various parties involved in the program. In implementing policies there are processes must be passed, including certain strategies and approaches that must be taken, as well as some completeness and adequacy that must be met. This is only for the sake of realizing success in implementing of policies.

Keywords: Policy Implementation, Education Policy, Policy Implementation Strategy

\section{PENDAHULUAN}

Langkah panjang dari suatu proses kebijakan bermuara pada bagian implementasi kebijakan itu sendiri. Sejatinya, proses implementasi kebijakan menjadi penentu akhir yang paling penting atas keseluruhan pembuatan kebijakan, termasuk dalam bidang pendidikan. Artinya, sebagus apapun rumusan dan formulasi kebijakan yang dihasilkan, menjadi tidak berarti manakala formulasi itu tidak dilanjutkan dengan proses implementasi. Oleh sebab itu, sesederhana apapun -untuk tidak mengatakan jelek atau burukrumusan dan formulasi kebijakan, jika dilaksanakan maka akan memiliki nilai manfaat.

Implementasi kebijakan merupakan bagian dari proses pembuatan kebijakan (policy making process). Seperti dinyatakan Hasbullah (2015), bahwa proses pembuatan kebijakan merupakan proses politik yang berlangsung dalam tahap-tahap pembuatan kebijakan politik, dimana aktivitas politis ini dijelaskan sebagai proses pembuatan kebijakan, dan divisualisasikan sebagai serangkaian tahap yang saling bergantung satu sama lainnya, diatur menurut urutan waktu, seperti penyusunan agenda, formulasi kebijakan, adopsi kebijakan, implementasi kebijakan, dan penilaian kebijakan.

Senada dengan pendapat di atas, Dunn (2003) mengilustrasikan secara rinci fase-fase dan karakteristik pembuatan kebijakan itu, di mana implementasi merupakan bagian didalamnya. Fase pertama, adalah penyusunan agenda, karakter fase ini misalnya para pejabat yang dipilih dan diangkat menempatkan masalah pada agenda publik. Fase kedua adalah formulasi kebijakan, karakter fase ini misalnya para pejabat merumuskan alternatif 
kebijakan untuk mengatasi masalah. Alternatif kebijakan melihat perlunya membuat perintah eksekutif, keputusan peradilan dan tindakan legislatif. Fase ketiga adalah adopsi kebijakan, karakter fase ini misalnya alternatif kebijakan yang diadopsi dengan dukungan dan mayoritas legislatif, konsensus di antara direktur lembaga, atau keputusan peradilan. Fase keempat adalah implementasi kebijakan, karakter fase ini misalnya kebijakan yang telah diambil dilaksanakan oleh unit-unit administrasi yang memobilisasikan sumber daya finansial dan manusia. Dan fase terakhir adalah penilaian kebijakan, karakter fase ini misalnya unit-unit pemeriksaan dan akuntansi dalam pemerintahan menentukan apakah badan-badan eksekutif, legislatif dan peradilan memenuhi persyaratan undangundang dalam pembuatan kebijakan dan pencapaian tujuan.

Secara umum, penulis menyimpulkan bahwa implementasi kebijakan adalah tahapan ketiga setelah tahap perumusan masalah kebijakan serta tahap formulasi dan adopsi kebijakan. Urutan berikutnya setelah tahap implementasi adalah tahap monitoring dan tahap evaluasi. Penentuan isi dan urutan tahapan proses kebijakan sendiri tidak bersifat statis. Perbedaan urutan dan isi dapat disebabkan oleh perbedaan perspektif dan teori yang digunakan dalam pengambilan kebijakan. Dengan demikian, penentuan ini berkembang secara dinamis sesuai dengan keragaman situasi dan kondisi yang dihadapi, misalnya meliputi keragaman stratifikasi kebijakan, jenis kebijakan dan lingkungan kebijakan (Hasbullah, 2015).

Berkaitan dengan keragaman dan perbedaan perspektif atau teori pengambilan kebijakan misalnya dapat ditelusuri dalam tulisan Anderson (2000) yang mengemukakan bahwa terdapat tiga teori utama yang dapat digunakan dalam proses pembuatan sebuah kebijakan yaitu: (1) Teori rasional-komprehensif merupakan teori yang intinya mengarahkan agar pembuatan sebuah kebijakan publik dilakukan secara rasional-komprehensif dengan mempelajari permasalahan dan alternatif kebijakan secara memadai. (2) Teori incremental adalah teori yang intinya tidak melakukan perbandingan terhadap permasalahan dan alternatif serta 
lebih memberikan deskripsi mengenai cara yang dapat diambil dalam membuat kebijakan. (3) Teori mixed scanning yaitu teori yang intinya menggabungkan antara teori rasional-komprehensif dengan teori inkremental.

Keragaman stratifikasi kebijakan misalnya dengan adanya kebijakan makro dan mikro (Hasbullah, 2015); kebijakan sentralistik dan desentralisasi (UU No 23 Tahun 2014 tentang Pemerintahan Daerah); kebijakan tingkat pusat dan kebijakan tingkat daerah; serta dapat pula dengan adanya kebijakan tingkat nasional (national policy level), tingkat umum (general policy level), tingkat khusus (special policy level) dan tingkat teknis (technical policy level) (Imron, 2008). Adapun keragaman jenis kebijakan seperti kategorisasi yang dikemukakan oleh Anderson (2000) meliputi substantive policies, procedural policies, distributive policies, redistributive policies, regulatory policies, selfregulatory policies, material policies, symbolic policies, collective good policies, private good policies, liberal policies, dan conservative policies.
Selain itu, Anderson (2000) juga mengemukakan enam kriteria yang harus dipertimbangkan dalam memilih kebijakan, yaitu: nilainilai yang dianut baik oleh organisasi, profesi, individu, kebijakan maupun ideologi; afiliasi partai politik; kepentingan konstituen; opini publik; penghormatan terhadap pihak lain; serta aturan kebijakan. Bahkan secara umum, para pakar ilmu politik melakukan kategorisasi jenis kebijakan ini kedalam kategori substantif (misalnya pendidikan, perburuhan, kesejahteraan sosial, hak-hak sipil), kategori kelembagaan (misalnya legislatif, yudikatif, departemen), dan kategori kebijakan menurut kurun waktu tertentu (misalnya kebijakan masa Reformasi, Orde Baru, dan Orde Lama). Keragaman lingkungan kebijakan seperti keragaman aspek sosial, politik, ekonomi dan budaya; lingkungan geografis dan lingkungan demografis; serta keragaman lainnya yang memiliki variabelvariabel relevan dengan konteks keragaman lingkungan kebijakan.

Namun, yang perlu dijadikan catatan dan perhatian bagi pengambil kebijakan adalah bahwa seluruh tahapan itu merupakan 
rangkaian proses yang saling berkesinambungan, tahapan yang satu dengan tahapan yang lainnya saling terkait dan tidak bisa dipisahkan. Mengingat begitu esensialnya pembahasan tersebut, dalam artikel ini penulis mengangkat topik tentang "Implementasi Kebijakan Pendidikan".

\section{METODE PENELITIAN}

Penelitian ini adalah penelitian kualitatif yang bersifat studi pustaka (library research) yang menggunkan buku-buku dan literatur-literatur lainnya sebagai objek yang utama (Hadi, 1995). Sebagai penelitian kepustakaan, metode yang digunakan untuk mengumpulkan data penelitian berupa data-data kepustakaan terutama buku-buku yang berkaitan tentang "implementasi kebijakan pendidikan". Kemudian data yang terkumpul dipilih, disajikan dan dianalisis serta diolah supaya ringkas dan sistematis. Adapun teknik analisi data dalam penelitian ini berupa analisis isi (content analysis) yaitu analis ilmiah tentang isi pesan suatu data (Muhadjir, 1998).
III. HASIL DAN PEMBAHASAN

1. Pengertian

Implementasi Kebijakan

Memahami pengertian implementasi kebijakan merupakan bagian dalam upaya memahami kebijakan secara komprehensif. Pada gilirannya, pemahaman itu menggiring pada pemahaman mengenai implementasi kebijakan dalam bidang pendidikan. Bahkan, implementasi kebijakan pendidikan seringkali berlangsung lebih rumit dan kompleks dibandingkan dengan proses perumusannya.

Istilah implementasi dalam Kamus Besar Bahasa Indonesia (KBBI) berarti pelaksanaan atau penerapan. Istilah implementasi biasanya dikaitkan dengan suatu kegiatan yang dilaksanakan untuk mencapai tujuan tertentu. Kamus Webster merumuskan secara pendek bahwa to implement (mengimplementasikan) berarti to provide the means for carryingout(menyediakan sarana untuk melaksanakan sesuatu), to give practical effect (menimbulkan dampak atau akibat terhadap sesuatu). Pengertian tersebut mempunyai arti bahwa untuk mengimplementasikan sesuatu 
harus disertai sarana yang mendukung yang nantinya akan menimbulkan dampak atau akibat terhadap sesuatu itu (Wahab, 2008).

Wibawa (1994) menyebutkan bahwa implementasi kebijakan merupakan bentuk pengejawantahan keputusan mengenai kebijakan yang mendasar. Biasanya tertuang dalam suatu undang-undang. Namun juga dapat berbentuk instruksi-instruksi yang penting atau keputusan perundang-undangan. Idealnya, keputusan-keputusan tersebut menjelaskan masalah-masalah yang hendak ditangani, menentukan tujuan yang hendak dicapai dan dalam berbagai cara "menggambarkan struktur" proses implementasi tersebut (Wibawa, 1994).

Implementasi kebijakan publik tidak hanya menyangkut perilaku badan-badan administratif yang bertanggung jawab untuk melaksanakan program dan menimbulkan ketaatan pada kelompok sasaran,melainkan pula menyangkut kekuatan-kekuatan politik, ekonomi, dan sosial yang langsung atau tidak langsung dapat mempengaruhi perilaku dari semua pihak yang terlibat,dan akhirnya berpengaruh terhadap dampak baik yang diharapkan.
Bahkan lebih dari itu, Grindle (1980) menyatakan bahwa implementasi kebijakan bukan hanya sekedar bersangkut paut dengan mekanisme penjabaran keputusan-keputusan politik ke dalam prosedur-prosedur rutin lewat saluran-saluran birokrasi, melainkan juga menyangkut masalah konflik kepentingan, keputusan, dan siapa yang memperoleh apa dari kebijakan tersebut.

Wahab (2008) menyatakan bahwa policy implementation encompasses those actions by public or private individuals groups that are directed the achievement of objecteves set forth in prior decision (tindakan-tindakan yang dilakukan oleh individu-individu atau pejabatpejabat atau kelompok-kelompok pemerintah atau swasta yang diarahkan pada tercapainya tujuantujuan yang telah digariskan dalam keputusan kebijakan). Tentang implementasi kebijakan, Udoji mengatakan dengan tegas bahwa The execution of policies is a important if not more important than policy-making. Policy will remain dreams or blue prints file jackets unless they are implemented (Pelaksanaan kebijakan adalah sesuatu yang penting, bahkan mungkin jauh 
lebih penting daripada pembuatan kebijakan. Kebijakan-kebijakan akan sekedar berupa impian atau rencana bagus yang tersimpan rapih dalam arsip jika tidak diimplementasikan). Oleh karena itu implementasi kebijakan perlu dilakukan secara arif, bersifat situasional, mengacu pada semangat kompetensi, dan berwawasan pemberdayaan.

Luankali (2007) berpendapat bahwa memahami apa yang senyatanya terjadi sesudah suatu program dinyatakan berlaku atau dirumuskan merupakan fokus perhatian implementasi kebijakan. Dapat dipahami bahwa implementasi merupakan kejadiankejadian atau kegiatan-kegiatan yang timbul sesudah disahkannya pedoman-pedoman kebijakan negara yang mencakup usahausaha untuk mengadministrasikannya maupun untuk menimbulkan akibat atau dampak nyata pada masyarakat atas kegiatan-kegiatan program yang sedang atau akan dilaksanakan.

$$
\text { Implementasi kebijakan }
$$

adalah suatu proses dinamis, dimana pelaksana kebijakan melakukan suatu aktivitas atau kegiatan sehingga pada akhirnya akan mendapatkan suatu hasil yang sesuai dengan tujuan atau sasaran kebijakan itu sendiri. Implementasi kebijakan publik terjadi karena tindakan-tindakan pemerintahan dalam mengatasi masalah yang timbul dalam masyarakat sehingga melahirkan keputusan-keputusan tersebut. Kebijakan ini dipandang sebagai proses perumusan kebijakan yang diterapkan, dilaksanakan dan dievaluasi melalui tahapan-tahapan (Awang, 2010).

Secara singkat Winarno (2008) mengatakan bahwa implementasi kebijakan merupakan suatu upaya untuk mencapai tujuantujuan tertentu dengan saranasarana tertentu dan dalam urutan waktu tertentu. Sementara itu Mufiz (1999), menyimpulkan bahwa implementasi kebijakan merupakan aktifitas-aktifitas yang dilakukan untuk melaksanakan suatu kebijaksanaan. Implementasi kebijakan merupakan rangkaian kegiatan setelah suatu kebijakan dirumuskan. Implementasi kebijakan haruslah menampilkan keefektifan dari kebijakan itu sendiri.

Berbeda dengan tahap formulasi atau tahapan-tahapan sebelumnya, dalam mengimplementasikan suatu 
kebijakan diperlukan lebih banyak yang terlibat baik tenaga kerja maupun kemampuan organisasi. Penerapan kebijakan bersifat interaktif dalam proses perumusan kebijakan. Penerapan sebagai sebuah proses interaksi antara suatu tujuan dan tindakan yang mampu untuk meraihnya. Penerapan merupakan kemampuan untuk membentuk hubungan-hubungan lebih lanjut dalam rangkaian sebab akibat yang menghubungan tindakan dengan tujuan.

Pada prinsipnya ada tiga hal yang perlu dipenuhi dalam hal efektivitas implementasi kebijakan. Pertama, apakah kebijakannya sudah tepat. Ketepatan kebijakan ini dinilai dari sejauh mana kebijaksanaan yang ada telah bermuatan hal-hal yang memecahkan masalah yang hendak dipecahkan. Kedua, apakah kebijakan tersebut sudah dirumuskan sesuai dengan karakter masalah yang hendak dipecahkan. Ketiga, apakah kebijakan dibuat oleh lembaga yang mempunyai kewenangan (misi kelembagaan) yang sesuai dengan karakter kebijakan (Nugroho, 2011).

Dengan demikian dapat disimpulkan bahwa implementasi kebijakan merupakan proses menjalankan, menyelenggarakan dan mengupayakan keputusan kebijakan dan alternatifnya yang telah telah diputuskandengan harapan akan memperoleh suatu hasil yang sesuai dengan tujuan atau sasaran dari suatu kebijakan. Tujuan dari implementasi kebijakan sendiri adalah untuk menetapkan arah agar tujuan kebijakan dapat direalisasikan. Proses implementasi kebijakan publik baru dapat dimulai apabila tujuan-tujuan kebijakan publik telah ditetapkan, programprogram telah dibuat, dan dana telah dialokasikan untuk pencapaian tujuan kebijakan tersebut.

\section{Proses}

Implementasi Kebijakan

Mengimplementasikan sebuah kebijakan bukanlah masalah yang mudah terutama dalam mencapai tujuan bersama. Cukup sulit untuk membuat sebuah kebijakan publik yang baik dan adil. Dan lebih sulit lagi untuk melaksanakannya dalam bantuk dan cara yang memuaskan semua orang termasuk mereka yang dianggap klien. Masalah lainnya adalah kesulitan dalam memenuhi tuntutan berbagai kelompok yang dapat menyebabkan konflik yang mendorong berkembangnya pemikiran politik sebagai konflik. 
Dalam proses implementasi kebijakan terdapat beberapa aspek yang berkaitan dengan proses ini dan layak untuk diperhatikan yaitu teori dan model implementasi kebijakan, pendekatan dalam implementasi kebijakan, langkahlangkah implementasi, faktorfaktor pelaksanaan kebijakan, serta tantangan dan kendala dalam keberhasilan implementasi kebijakan. Pembahasan tiga aspek terakhir akan dikemukakan dalam pembahasan mengenai strategi implementasi serta kecukupan dan kelengkapan implementasi kebijakan.

Terdapat cukup banyak teori dan model yang menjelaskan tentang implementasi kebijakan, termasuk kebijakan dalam bidang pendidikan. Beberapa diantaranya seperti yang sampaikan oleh Wahab (2008) adalah teori Brian W. Hogwood dan Lewis A. Gunn, teori Van Meter dan Van Horn, serta teori Daniel Mazmanian dan Paul A. Sabatier.

Brian W. Hogwood dan Lewis A. Gunn merupakan pencetus teori implementasi kebijakan dengan pendekatan The top down approach. Menurutnya, terdapat beberapa syarat agar kebijakan dapat dilaksanakan secara sempurna yaitu:

a. Kondisi eksternal yang dihadapi oleh Badan atau Instansi pelaksana tidak akan menimbulkan gangguan serta kendala yang serius.

b. Tersedianya waktu dan sumber yang cukup memadai untuk pelaksanaan program.

c. Perpaduan sumber-sumber yang diperlukan benar-benar tersedia.

d. Kebijakan yang akan diimplementasikan didasari oleh suatu hubungan kausalitas yang andal.

e. Hubungan kausalitas bersifat langsung dan hanya sedikit mata rantai penghubungnya.

f. Hubungan saling ketergantungan harus sedikit.

g. Pemahaman yang mendalam dan kesepakatan terhadap tujuan.

h.Tugas-tugas diperinci dan ditempatkan dalam urutan yang tepat.

i. Komunikasi dan koordinasi yang sempurna.

j.Pihak-pihak yang memiliki wewenang dan kekuasaan dapat menuntut dan mendapatkan kepatuhan yang sempurna.

Teori dan model yang dikembangkan oleh Van Meter dan Van Horn seringkali disebut sebagai A model of the policy 
implementation process (model proses implementasi kebijakan) dimana dalam teorinya beranjak dari suatu argumen bahwa perbedaan-perbedaan dalam proses implementasi akan dipengaruhi oleh sifat kebijaksanaan yang akan dilaksanakan (Wahab, 2008). Selanjutnya mereka menawarkan suatu pendekatan yang mencoba untuk menghubungkan antara isu kebijakan dengan implementasi dan suatu model konseptual yang mempertalikan kebijakan dengan prestasi kerja (performance). Kedua ahli ini menegaskan pula pendiriannya bahwa perubahan, kontrol dan kepatuhan bertindak merupakan konsep-konsep penting dalam prosedur-prosedur implementasi. Van Meter dan Van Horn (1975) kemudian berusaha membuat tipologi kebijakan sebagai berikut:

a.Jumlah masing-masing perubahan yang akan dihasilkan b.Jangkauan atau ruang lingkup kesepakatan terhadap tujuan diantara pihak-pihak yang terlibat dalam proses implementasi.

Alasan yang dikemukakannya disini ialah bahwa proses implementasi itu akan dipengaruhi oleh dimensidimensi kebijaksanaan semacam itu, dalam artian bahwa kebanyakan implementasi akan berhasil apabila perubahan yang dikehendaki relatif sedikit, sementara kesepakatan terhadap tujuan-terutama dari mereka yang mengoperasikan program dilapangan- relatif tinggi.

Van Meter dan Van Horn (1975) menyatakan bahwa suatu kebijakan tentulah menegaskan standar dan sasaran tertentu yang harus dicapai oleh para pelaksana kebijakan. Kinerja kebijakan pada dasarnya merupakan penilaian atas tingkat ketercapaian standar dan sasaran tersebut. Lebih sederhana lagi kinerja (performance) merupakan tingkat pencapaian hasil atau the degree of accomplishment.

Dalam model Van Meter dan Van Horn (1975) ini ada enam variabel yang dapat meningkatkan kejelasan antara kebijakan dan kinerja implementasi, yaitu:pertama, standar dan sasaran kebijakan; kedua, komunikasi antar organisasi dan pengukuran aktivitas; ketiga, karakteristik organisasi komunikasi antar organisasi; keempat, kondisi sosial, ekonomi dan politik; kelima, sumber daya; keenam sikap atau karakter pelaksana. 
Teori dan model berikutnya adalah teori dan model yang dikembangkan oleh Daniel Mazmanian dan Sabatier (1985). Teori dan model ini disebut $A$ frame work for implementation analysis (kerangka analisis implementation) (Wahab, 2008). Kedua ahli ini berpendapat bahwa peran penting dari analisis implementasi kebijaksanaan negara ialah mengidentifikasikan variabelvariabel yang mempengaruhi tercapainya tujuan-tujuan formal pada keseluruhan proses implementasi. Variabel-variabel yang dimaksud dapat diklasifikasikan menjadi tiga kategori besar, yaitu:

a. Mudah tidaknya masalah yang akan digarap untuk dikendalikan

b.Kemampuan

keputusan kebijaksanaan untuk menstrukturkan secara tepat proses implementasinya

c.Pengaruh langsung berbagai variabel politik terhadap keseimbangan dukungan bagi tujuan yang termuat dalam keputusan kebijaksanaan tersebut.

Terakhir, teori dan model yang dikembangkan oleh George C. Edwards III. Menurutnya terdapat empat faktor atau variabel krusial dalam implementasi kebijakan publik, yaitu komunikasi (communication), sumber daya (resources), kecenderungan tingkah laku atau sikap (disposition atau attitude), serta struktur birokrasi (bereucratic structure) (Winarno, 2008).

\section{a. Komunikasi}

(communication). Edwards menyebutkan tiga hal penting dalam proses komunikasi kebijakan, yakni transmisi(transmition), kejelasan (clarity), dan konsistensi (consistency).

- $\quad$ Transmisi (transmition); Sebelum pejabat dapat mengimplementasikan suatu keputusan, ia harus menyadari bahwa suatu keputusan telah dibuat dan suatu perintah untuk pelaksanaannya telah dikeluarkan. Ada beberapa hambatan yang timbul dalam mentransmisikan perintah-perintah yang diimplementasikan. Pertama, pertentangan pendapat antara pelaksana dengan perintah yang dikeluarkan oleh pengambil kebijakan. Kedua, informasi melewati berlapis-lapis birokrasi. Ketiga, penangkapan komunikasi dihambat oleh persepsi yang selektif dan ketidakmauan para pelaksana untuk mengetahuhi 
persyaratan-persyaratan suatu kebijakan.

- Kejelasan (clarity); Jika kebijakan diimplementasikan sebagaimana yang diinginkan, maka bukan hanya petunjuk pelaksanaan itu harus diterima oleh para pelaksana kebijakan tapi juga komunikasi kebijakan tersebut harus jelas. Dalam beberapa kasus, para pelaksana sama sekali tidak memahami tujuan-tujuan suatu kebijakan atau persyaratanpersyaratan operasionalnya. Bahkan dalam beberapa kasus lainnya, para pelaksana membuat usaha untuk mengekploitasi kekaburan dalam komunikasi dengan tujuan untuk kepentingan mereka sendiri. Kurangnya kejelasan memungkinkan timbulnya perubahan kebijakan yang tidak diharapkan.

- Konsistensi (concistency); Jika implementasi kebijakan ingin berlangsung efektif, maka perintahperintah pelaksanaannya harus konsisten dan jelas. Jika perintah yang disampaikan inkonsisten, hal ini akan menyulitkan para pelaksana kebijakan dalam menjalankan tugasnya dengan baik. Di sisi lain, perintah-perintah implementasi kebijakan yang tidak konsisten akan mendorong para pelaksana mengambil tindakan yang sangat longgar dalam menafsirkan dan mengimplementasikan kebijakan. Akibatnya, jika kebijakan bertentangan dengan pilihan atau kepentingan pelaksana, maka mereka akan cenderung menggunakan keleluasaannya untuk mengabaikan dan atau mendistorsikannya. Ketidakkonsistenan -seperti halnya kekaburan- berasal dari semakin besarnya kepentingan yang bersaing dan berusaha untuk mempengaruhi implementasi kebijakan.

b. Sumber Daya (resources). Sumber daya merupakan faktor penting dalam melaksanakan kebijakan publik. Sumber daya itu meliputi staf yang memadai disertai keahlian yang baik untuk melaksanakan tugasnya, informasi, wewenang dan fasilitas-fasilitas yang diperlukan untuk menterjemahkan usul-usul di atas kertas guna melaksanakan pelayanan publik.

- $\quad$ Staf; Merupakan sumber paling penting dalam melaksanakan kebijakan karena merekalah pelaksana kebijakan di lapangan. Dalam hal ini, tentu saja jumlahnya harus cukup dan harus 
mempunyai keterampilan yang diperlukan untuk melaksanakan kebijakan.

- Informasi; Yang dimaksud disini adalah, pertama, informasi mengenai bagaimana melaksanakan suatu kebijakan. Pelaksana perlu mengetahui apa yang dilakukan dan bagaimana mereka harus melakukannya. Dengan demikian para pelaksana kebijakan harus diberi petunjuk untuk melaksanakan kebijakan. Kedua, data tentang ketaatan personil-personil lain terhadap peraturan-peraturan pemerintah. Kurangnya informasi tentang bagaimana mengimplementasikan kebijakan akan berakibat langsung terhadap ketidak-terpenuhiannya tanggung jawab sesuai dengan waktunya.

- Wewenang; Terbatas atau kurangnya wewenang dalam melakukan suatu kebijakan bisa menjadi suatu hambatan. Namun bisa juga suatu badan mempunyai wewenang besar namun tidak efektif dalam menggunakan wewenang tersebut. Dalam hal ini efektifitas dalam penggunaan wewenang sangat diperlukan.

- $\quad$ Fasilitas-fasilitas; Meliputi fasilitas-fasilitas fisik yang merupakan sumber penting dalam implementasi karena menjadi faktor pendukung terlaksananya sebuah kebijakan.

c. Kecenderungan Tingkah Laku atau Sikap (disposition atau attitude). Kecenderungan ini berkenaan dengan kesediaan dari para implementor untuk mengeksekusi kebijakan tersebut. Kecakapan saja tidak mencukupi, tanpa kesediaan dan komitmen untuk melaksanakan kebijakan. Menurut Edwards, banyak kebijakan yang masuk ke dalam "zona ketidakacuhan". Ada kebijakan yang dilaksanakan secara efektif karena mendapat dukungan dari pelaksana kebijakan, namun kebijakankebijakan lain mungkin akan bertentangan secara langsung dengan pandangan pelaksana kebijakan dan kepentingan pribadi atau organisasi pelaksana. Dalam kasus seperti ini para pelaksana kebijakan akan mengunakan keleluasaan dan kadang-kadang dengan cara-cara yang halus menghambat implementasi.

d. Struktur Birokrasi (bereucratic structure). Struktur birokrasi (bereucratic structure) berkenaan dengan kesesuaian organisasi birokrasi yang menjadi penyelenggara implementasi 
kebijakan. Birokrasi merupakan salah satu badan yang paling sering bahkan secara keseluruhan menjadi pelaksana kebijakan. Struktur organisasi yang mengimplementasikan kebijakan memiliki pengaruh yang signifikan terhadap implementasi kebijakan. Salah satu aspek struktur yang penting dari setiap organisasi adalah adanya prosedur operasional yang standar yang dapat menjadi pedoman bagi setiap implementator dalam bertindak.

Berkenaan dengan pendekatan yang dapat digunakan dalam implementasi kebijakan, sebagaimana dijelaskan Hasbullah (2015), setidaknya terdapat 4 (empat) pendekatan, yaitu:

a. Pendekatan Struktural. Pendekatan struktural ini merupakan salah satu pendekatan yang bersifat top-down. Pendekatan ini memandang bahwa setiap kebijakan, termasuk pula kebijakan pendidikan, harus dirancang, diimplementasikan, dan dievaluasi secara struktural. Pendekatan ini menekankan pentingnya komando dan supervisi menurut tahapan atau tingkatan dalam struktur masing-masing organisasi. Pendekatan ini bersifat hirarkis-organis, sehingga relevan untuk situasi-situasi implementasi dimana didalamnya diperlukan organisasi pelaksana yang bertingkat dengan pola perubahan kebijakan yang tinggi.

b. Pendekatan Prosedural dan Manajerial. Pendekatan ini dikembangkan untuk mengatasi kelemahan pada pendekatan struktural. Pendekatan ini berupaya mengembangkan proses-proses dan prosedur-prosedur yang relevan baik prosedur manajerialnya maupun teknik manajemennya.

c. Pendekatan Perilaku. Pendekatan ini meletakan dasar semua orientasi dari kegiatan implementasi kebijakan pada perilaku manusia sebagai pelaksana bukan pada organisasinya sebagaimana dua pendekatan sebelumnya. Pendekatan ini berasumsi bahwa upaya implementasi kebijakan yang baik adalah bila perilaku manusia beserta segala sikapnya juga harus dipertimbangkan dan dipengaruhi agar proses implementasi kebijakan tersebut dapat berlangsung baik.

d. Pendekatan Politik.

Pendekatan ini lebih melihat pada faktor-faktor politik atau kekuasaan yang dapat 
memperlancar atau menghambat proses implementasi kebijakan. Pendekatan politik selalu mempertimbangkan atas pemantauan kelompok pengikut dan kelompok penentang beserta dinamikanya. Dalam pendekatan ini, memungkinkan digunakannya paksaan dari kelompok dominan.
3. Strategi dan Langkah-

Langkah Implementasi Kebijakan

Dalam penerapan strategi implementasi kebijakan, sebetulnya dapat mengacu pada model, teori dan pendekatan yang sudah penulis sampaikan di atas. Adapun untuk langkah-langkah implementasi, ada baiknya diketahui dulu tata urutan implementasi kebijakan seperti terlihat dalam gambar di bawah ini:

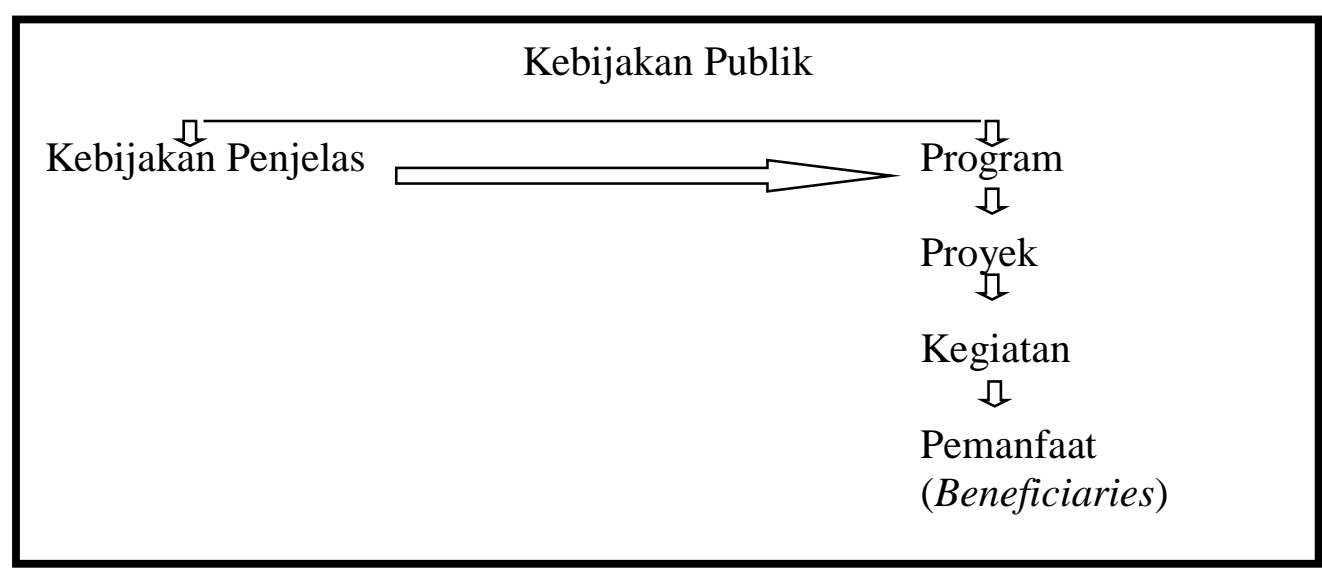

Gambar 1 diadaptasi dari William N. Dunn (2003)
Gambar 1 Tata Urutan
controling. Dengan demikian Implementasi KebijakanTujuan kebijakan adalah melakukan intervensi. Oleh karena itu, implementasi kebijakan sebenarnya adalah tindakan(action) intervensi itu sendiri. Implementasi kebijakan dalam konteks manajemen adalah berada dalam kerangka Organizing-leadingketika kebijakan sudah dibuat maka tugas penting yang mesti dilaksanakan adalah mengorganisasikan dan melaksanakan kepemimpinan untuk mengarahkan pelaksanaan dan melakukan pengendalian pelaksanaan kebijakan tersebut. 
Agar dapat melakukan intervensi secara optimal, Mazmanian \& Sabatier (1985) menyebutkan bahwa beberapa faktor perlu diperhatikan dalam implementasi, yakni: Pertama, mengidentifikasi masalah yang harus diintervensi; Kedua, Menegaskan tujuan yang hendak dicapai; Ketiga, Merancang strukturproses implementasi. Untuk menyusun struktur implementasi tersebut terdapat halhal yang harus diperhatikan meliputi:

a. Pembentukan unit organisasi atau staf pelaksana

b. Penjabaran tujuan dalam berbagai aturan pelaksana (Standard operating procedures/SOP)

c. Mengkoordinasikan berbagai sumberdaya dan pengeluaran pada kelompok sasaran serta pembagian tugas diantara badan pelaksana

d. Pengalokasian sumberdaya untuk mencapai tujuan.

Hampir tidak ada literatur mengenai implementasi yang membahas bagaimana petunjuk penyusunan struktur (langkahlangkah) implementasi. Hal ini karena masing-masing kebijakan memiliki tujuan dan tipenya sendiri, sehingga kebutuhan akan struktur pengimplementasiannya pun dapat berbeda, bergantung pada metode penyampaian (delivery system) yang dipandang sesuai untuk itu. Terlebih lagi struktur implementasi lebih dipandang sebagai the matter of organization atau management of a programme.

Dalam Permenpan No. 4 tahun 2007 tentang Pedoman Umum Formulasi, Implementasi, Evaluasi Kinerja dan Revisi Kebijakan Publik di Lingkungan Lembaga Pemerintah Pusat dan Daerah; terdapat langkah-langkah yang ditempuh dalam mengimplementasikan kebijakan publik, yaitu:

a. Penyiapan Implementasi Kebijakan, termasuk kegiatan sosialisasi dan pemberdayaan para pihak yang menjadi pelaksana kebijakan pendidikan, baik dari kalangan pemerintah atau birokrasi maupun masyarakat (publik). Tahapan sosialisasi dilakukan dengan cara penyebarluasan informasi kepada masyarakat melalui berbagai media serta pertemuan langsung dengan masyarakat.

b. Implementasi kebijakan yang dilaksanakan tanpa sanksi 
(masa uji coba) dengan jangka waktu tertentu disertai dengan perbaikan atau penyempurnaan kebijakan apabila diperlukan.

c. Implementasi kebijakan yang dilaksanakan dengan sanksi. Hal ini dilakukan setelah masa uji coba selesai, disertai dengan pengawasan dan pengendalian.

d. Setelah dilakukan implementasi kebijakan, lalu dilakukanlah evaluasi kebijakan.

\section{Kecukupan dan Kelengkapan} Implementasi Kebijakan

Keberhasilan implementasi kebijakan dapat dilihat dari terjadinya kesesuaian antara pelaksanaan atau penerapan kebijakan dengan desain, tujuan dan sasaran kebijakan itu sendiri, serta memberikan dampak atau hasil yang positif bagi pemecahan masalah yang dihadapi. Asumsi yang dibangun mengenai konsep keberhasilan implementasi kebijakan adalah semakin tinggi derajat kesesuaiannya, maka semakin tinggi pula peluang keberhasilan kinerja implementasi kebijakan untuk menghasilkan output yang telah digariskan.

Beberapa faktor yang dapat dijadikan perhatian dalam keberhasilan implementasi kebijakan berdasarkan pembahasan di atas antara lain, faktor manusia, faktor struktur kebijakan, faktor proses administrasi dan manajemen, faktor dana, dan faktor daya.

Menurut Hogwood dan Gun (Garret, 1993), bahwa kebijakan publik mengandung resiko untuk gagal. Keduanya membagi dua pengertian tentang kegagalan kebijakan (policy failure), yaitu :

a. Tidak terimplementasikan (non implementation). Suatu kebijakan yang tidak dilaksanakan sesuai dengan rencana dan pada akhirnya berakibat pada implementasi yang tidak efektif dan sulit untuk dipenuhi.

b. Implementasi yang tidak berhasil (unsucessfull implementation).Implementasi yang tidak berhasil biasanya terjadi manakala suatu kebijakan tertentu telah dilaksanakan sesuai dengan rencana namun karena ada faktor eksternal akhirnya kebijakan itu tidak berhasil untuk mencapai hasil yang dikehendaki. Kebijakan memiliki resiko gagal karena faktor berikut: Pelaksanaan buruk (bad excecution), kebijakan itu sendiri buruk (bad policy) dan kebijakan itu sendiri yang bernasib buruk (bad luck). 
Peter mengatakan, implementasi kebijakan yang gagal disebabkan oleh beberapa faktor (Tangkilisan, 2003):

a. Kekurangan informasi sehingga menyebabkan gambaran gambaran yang kurang tepat mengenai isi kebijakan yang sesungguhnya. Gambaran yang kurang jelas ini berdampak buruk kepada objek kebijakan maupun kepada pelaksana dari isi kebijakan yang akan dilaksanakan dan hasil dari kebijakan itu. Hal ini juga menghindari kesalahpahaman dan agar menyamakan persepsi antara kedua belah pihak.

b. Isi kebijakan yang samarsamar dan tidak jelas atau tidak tegas.Implementasi kebijakan bisa gagal karena masih samarnya isi atau tujuan kebijakan atau ketidaktepatan intern maupun ekstern kebijakan itu sendiri dan menunjukkan adanya kekurangan yang sangat berarti atau adanya kekurangan yang menyangkut sumber daya.

c. Tidak cukupnya dukungan dalam melaksanakan kebijakan.Implementasi kebijakan akan sangat sulit apabila pada pelaksanaannya tidak cukup dukungan terhadap kebijakan tersebut. d. Pembagian potensi yang bersifat diferensiasi tugas dan wewenang para aktor implementasi kebijakan.

Terdapat beberapa faktor yang bekerja dalam proses implementasi kebijakan. Menurut Goggin, kebijakan diasumsikan sebagai suatu pesan dari pemerintah federal(pusat) kepada pemerintah daerah. Keberhasilan implementasi pesan tersebut sangat dipengaruhi oleh 3 hal pokok (Purwanto \& Sulistyastuti, 2012):

a. Isi kebijakan (the content of the policy message) meliputi sumberdaya, manfaat kebijakan, serta ketertiban publik

b. Format kebijakan (the form of the policy message) tediri dari kejelasan kebijakan (policy clarity), konsistensi kebijakan (policy consistencly), frequency serta penerimaan isi kebijakan (receipt of message)

c. Reputasi actor (the reputation of the communicator) terdiri dari legitimasi dan kredibilitas aktor-aktor pemerintah daerah.

Apabila disepakati bahwa cara melihat keberhasilan implementasi tidak hanya berhenti pada kepatuhan para implementor saja, namun juga hasil yang dicapai 
setelah prosedur implementasi dijalani, maka upaya untuk memahami realitas implementasi kebijakan perlu dilihat secara lebih detil dengan mengikuti proses implementasi yang dilalui para implementor dalam upaya untuk mewujudkan tujuan kebijakan tersebut.

Pada dasarnya indikator kinerja untuk menilai derajat pencapaian standar dan sasaran kebijakan dapat dijelaskan bahwa kegiatan itu melangkah dari tingkat kebijakan yang masih berupa dokumen peraturan menuju penentuan standar spesifik dan kongkrit dalam menilai kinerja program. Dengan standar dan sasaran dapat diketahui seberapa besar keberhasilan program yang telah dicapai.

Ripley dan Franklin dalam bukunya yang berjudul "Birokrasi dan Implementasi Kebijakan (policy implementation and bureaucracy)" menyatakan bahwa keberhasilan implementasi kebijakan atau program dapat ditujukan dari tiga faktor yaitu (Wahab, 2008):

a. Perspektif kepatuhan (compliance) yang mengukur implementasi dari kepatuhan strect level bereau crats terhadap atasan mereka.

b. Keberhasilan implementasi diukur dari kelancaran rutinitas dan tiadanya persoalan.

c. Implementasi yang berhasil mengarah kepada kinerja yang memuaskan semua pihak terutama kelompok penerima manfaat yang diharapkan.

Secara sederhana ketiga faktor diatas merupakan suatu kepastian dalam menilai keberhasilan suatu implementasi kebijakan sehingga kurang atau hilangnya salah satu faktor mempengaruhi sekali terhadap kinerja kebijakan tersebut.

Kemudian sebaliknya, Jan Merse mengemukakan bahwa ada empat faktor yang dapat menimbulkan kegagalan dalam implementasi kebijakan yaitu (Hasbullah, 2015):

a. Isu kebijakan. Isi kebijakan harus jelas dan tegas serta mengandung muatan-muatan politik yang mengakomodir kepentingan seluruh stakeholders. Implementasi kebijakan dapat gagal karena masih samarnya isi atau tujuan kebijakan, ketidaktegasan intern maupun ekstern atau ketidaktepatan kebijakan itu sendiri. Hal ini 
menunjukan adanya kekurangan yang menyangkut sumber daya pendukungnya.

b. Informasi. Kekurangan informasi dengan mudah mengakibatkan adanya gambaran yang kurang tepat baik kepada objek kebijakan maupun kepada para pelaksana dari isi kebijakan yang akan dilaksanakannya dan hasil-hasil dari kebijakan itu.

c. Dukungan. Implementasi kebijakan publik akan sangat sulit bila pada pelaksanaanya tidak cukup dukungan untuk kebijakan tersebut. Dukungan ini dapat berupa fisik ataupun non fisik. Dukungan inipun berkaitan dengan partisipasi masyarakat dalam pelaksanaan kebijakan.

d. Pembagian potensi. Pada dasarnya hal ini berkaitan dengan kinerja koordinasi masyarakat luas. Koordinasi dibutuhkan karena setiap pelaku memiliki latar belakang kepentingan dan keinginan yang berbeda. Koordinasi menjadi titik temu dan sentral bagi keberhasilan kebijakan.

Implementasi kebijakan haruslah menampilkan keefektifan dari kebijakan itu sendiri. Menurut Nugroho (2011), pada dasarnya ada lima hal yang perlu dipenuhi dalam hal keefektifan implementasi kebijakan, yaitu :

a. Apakah kebijakannya sendiri sudah tepat. Ketepatan kebijakan dinilai dari sejauh mana kebijakan yang ada telah bermuatan hal-hal yang memang memecahkan masalah yang hendak dipecahkan.

b. Ketepatan pelaksana. Aktor implementasi tidaklah hanya pemerintah, ada tiga lembaga yang dapat menjadi pelaksana, yaitu pemerintah, kerjasama antara pemerintah masyarakat/swasta atau implementasi kebijakan yang diswastakan (privatization atau contracting out).

c. Ketepatan target implementasi.

Ketepatan berkenaan dengan tiga hal, yaitu: a) Apakah target yang diintervensi sesuai dengan yang direncanakan, apakah tidak ada tumpang tindih dengan intervensi yang lain, atau tidak bertentangan dengan intervensi kebijakan lain; b) Apakah targetnya dalam kondisi siap untuk diintervensi ataukah tidak, kesiapan bukan saja dalam arti secara alami, namun juga apakah kondisi target ada dalam konflik atau harmoni, dan apakah kondisi target ada dalam kondisi mendukung atau menolak; c) 
Apakah intervensi implementasi kebijakan bersifat baru atau memperbarui implementasi kebijakan sebelumnya.

d. Apakah lingkungan implementasi sudah tepat. Ada dua lingkungan yang paling menentukan, yaitu a) lingkungan kebijakan, merupakan interaksi diantara lembaga perumus kebijakan dan pelaksana kebijakan dan lembaga lain yang terkait; b) lingkungan eksternal kebijakan yang terdiri atas public opinion, yaitu persepsi publik akan kebijakan dan imlementasi kebijakan, interpretive institutions yang berkenaan dengan interprestasi dari lembaga-lembaga strategis dalam masyarakat.

e. Tepat proses. Secara umum implementasi kebijakan publik terdiri atas tiga proses, yaitu: 1) policy acceptane, di sini publik memahami kebijakan sebagai sebuah aturan main yang diperlukan untuk masa depan, di sisi lain pemerintah memahami kebijakan sebagai tugas yang harus dilaksanakan; 2) policy adoption, publik menerima kebijakan sebagai sebuah aturan main yang diperlukan untuk masa depan, disisi lain pemerintah menerima kebijakan sebagai tugas yang harus dilaksanakan; 3) strategic readiness, publik siap melaksanakan atau menjadi bagian dari kebijakan, di sisi lain birokrat pelaksana siap menjadi pelaksana kebijakan.

William N. Dunn (2003) mengemukakan bahwa keberhasilan implementasi kebijakan dapat dicapai jika memperhatikan 2 hal, yaitu:

a.Policy stakeholder, yaitu para individu atau kelompok individu yang mempunyai andil di dalam kebijakan, karena mereka memengaruhi dan dipengaruhi oleh keputusan pemerintah lingkungan dimana kebijakan akan diterapkan.

b.Policy environment, yaitu konteks khusus dimana kejadian-kejadian di sekeliling isu kebijakan akan terjadi saling memengaruhi oleh kebijakan publik.

Imron (2008) melakukan perincian terhadap faktor-faktor yang berpengaruh terhadap implementasi kebijakan terutama di bidang pendidikan, yaitu sebagai berikut:

a.Kompleksitas kebijakan-kebijakan yang telah dibuat. Semakin kompleks suatu kebijakan, akan semakin rumit dan lama implementasinya. Bahkan kompleksitas rumusan kebijakan 
juga berakibat pada banyaknya peraturan-peraturan jabaran, petunjuk pelaksanaan, dan petunjuk teknis, yang harus dibuat. Tidak jarang pula kompleksitas itu menimbulkan banyak tafsiran dari para pelaksananya.

b.Tidak jelasnya rumusan kebijakan dan pemecahan masalah yang diajukan. Ketidak jelasan ini menimbulkan sikap keraguan pada diri pelaksana kebijakan serta kekhawatiran andaikata pelaksanaannya tidak sesuai dengan rumusan.

c.Faktor sumber-sumber potensial yang dapat mendukung pelaksanaan kebijakan. Faktorfaktor ini harus tersedia jika pelaksanaan kebijakan ingin berhasil.

d.Keahlian pelaksana kebijakan. Semakin profesional pelaksana kebijakan, baik teknis maupun manajerialnya, maka akan semakin baik pula implementasi kebijakan. e.Dukungan dari khalayak (masyarakat) sasaran terhadap kebijakan yang diimplementasikan f.Faktor efektivitas dan efisiensi birokrasi. Kegagalan implementasi kebijakan adakalanya disebabkan oleh birokrasi dan aparatnya yang tidak mendukung.
Terdapat beberapa instrumen untuk memenuhi kelengkapan dan kecukupan implementasi kebijakan yaitu: Hukum, services (pelayanan), dana, pajak, dan situasi (Hasbullah, 2015). 1) Hukum merupakan instrumen paling umum yang digunakan oleh pemerintah. Dengan menetapkan suatu hukum, pemerintah mempunyai legitimasi untuk dapat melaksanakan suatu kebijakan yang dapat memaksa setiap warga negara untuk mentaatinya. 2) Services (pelayanan), pelaksanaan kebijakan dapat berupa pelayanan kepada masyarakat oleh pemerintah. Namun harus dijadikan catatan bahwa pelayanan yang baik adalah pelayanan yang sampai kepada yang membutuhkan. 3) Dana diperlukan sebagai sumber daya untuk membiayai semua kegiatan pelayanan dan pelaksanaan kebijakan. 4) Pajak merupakan instrumen yang dikelola oleh pemerintah untuk dikembalikan lagi kepada masyarakat melalui berbagai bentuk program yang lebih baik dan memberikan keuntungan pada masyarakat. 5) Situasi merupakan instrumen yang digunakan oleh pemerintah manakala instrumen-instrumen di 
atas gagal. Instrumen ini dapat berupa penggunaan keyakinan moral untuk memengaruhi masyarakat.

Kelengkapan lainnya untuk implementasi kebijakan adalah adanya organisasi, baik pemerintah maupun non-pemerintah. Tipe organisasi ideal yang menjamin keberhasilan implementasi kebijakan adalah:

a. Adanya kesatuan dalam organisasi; kendala pada poin ini terletak pada adanya perbedaan pandangan atau persepsi dalam melihat suatu masalah.

b. Standar pelaksanaan prosedur yang jelas.

c. Mekanisme komunikasi dalam organisasi yang baik

d. Tidak ada masalah waktu (time problem) dalam implementasi; kendala pada poin ini adalah kelambatan komunikasi dan hilangnya momentum yang tepat dalam implementasi.

e. Tidak ada masalah informasi dalam implementasi; kendalanya adalah akumulasi kesalahan penyampaian informasi dari bawah ke atas.

\section{KESIMPULAN}

Implementasi merupakan faktor terpenting dari sebuah kebijakan yang dilakukan, termasuk dalam hal ini kebijakan dalam bidang pendidikan. Implementasi kebijakan, termasuk kebijakan pendidikan, merupakan proses yang bersangkut paut dengan perilaku badan administratif sebagai penanggung jawab pelaksanaan program dan menimbulkan ketaatan pada kelompok sasaran. Proses implementasi bersangkut paut pula dengan faktor hukum, politik, ekonomi, sosial yang langsung maupun tidak langsung berpengaruh terhadap perilaku dari berbagai pihak yang terlibat dalam program. Tujuan implementasi kebijakan adalah untuk menetapkan arah agar tujuan kebijakan dapat direalisasikan. Dalam implementasi kebijakan terdapat proses yang harus dilalui, strategi dan pendekatan tertentu yang harus ditempuh, serta beberapa kelengkapan dan kecukupan yang harus dipenuhi. Hal ini semata demi mewujudkan keberhasilan dalam implementasi suatu kebijakan. Demikian pula halnya kebijakan dalam bidang pendidikan. 


\section{DAFTAR PUSTAKA}

Anderson, J. A., (2000). Public Policy Making. New York: Holt, Rinehart \& Winston)

Awang, A. (2010). Impelementasi Pemberdayaan Pemerintah Desa. Yogyakarta: Pustaka Pelajar.

Dunn, W. N. (2003). Pengantar Analisis Kebijakan Publik Edisi Kedua. Yogyakarta: Gadjah Mada University Press.

Garret, James E. (1993). Public Administration and Policy Implementation: A Social Work Perspektive. International Journal of Public Administration.

Grindle, M. S. (1980). Politics and Policy Implementation in The Third World. New Jersey: Princeton University Press.

Hadi, S. (1995). Statistik II. Jakarta: PT. Rineka Cipta.

Hasbullah, H.M. (2015). Kebijakan Pendidikan; Dalam Perspektif Teori, Aplikasi, dan Kondisi Objektif Pendidikan di Indonesia. Jakarta: Rajawali Pers.

Imron, A. (2008). Kebijaksanaan Pendidikan di Indonesia; Proses, Produk dan Masa Depannya. Jakarta: Bumi Aksara.

Luankali, B. (2007). Analisis Kebijakan Publik Dalam Proses Pengambilan Keputusan. Bandung: IPDN.

Mazmanian, D, H \& Sabatier, P. A. (1983). Implementation and Public Policy. New York: HarperCollins

Mufiz, A. (1999). Pengantar Administrasi Negara (Jakarta:Universitas Terbuka Depdikbud). 
Muhadjir, N. (1998). Metodologi Penelitian Kualitatif. Yogyakarta: Rake Sarasin.

Nugroho, R. D. (2011). Public Policy; Dinamika Kebijakan, Analisis Kebijakan, Manajemen Kebijakan, Edisi Ketiga Revisi. Jakarta: Elex Media Komputindo.

Purwanto, E. A \& Sulistyastuti, D. R. (2012). Implementasi Kebijakan Publik. Yogyakarta: Gapa Media.

Tangkilisan, H. N. S. (2003). Kebijakan Publik Yang Membumi. Yogyakarta: Yayasan Pembaruan Administrasi Publik.

UU No 23 Tahun 2014 tentang Pemerintahan Daerah

Van Meter, D \& Van Horn, C. E. (1975). The Policy Implementation Process. Sage Publication: Beverly Hill.

Wahab, S. A. (2008). Analisis Kebijaksanaan; Dari Formulasi ke Implementasi Kebijaksanaan Negara. Jakarta: Bumi Aksara.

Wibawa, S. (1994). Kebijakan Publik; Proses dan Analisis. Jakarta: Intermedia.

Winarno, B (2008). Kebijakan Publik; Teori dan Proses. Yogyakarta: MedPress. 